\title{
In Vitro Activation of Adenylate Cyclase of Atrophic Celiac Intestinal Mucosa by Wheat Gliadin-Derived Peptides
}

\author{
L. BEGUINOT, S. AURICCHIO, J. E. BERNARDIN, G. DE RITIS, M. DE VINCENZI
}

\author{
D. D. KASARDA, V. MACCHIA, AND V. SILANO
}

\begin{abstract}
Istituto di Patologia Generale [L.B., V.M.]; Clinica Pediatrica [S.A., G.R.], II Facoltà di Medicina e Chirurgia and Gruppo di Ricerca del Consiglio Nazionale della Ricerche sulla Fisiologia e Patologia dell'Apparato Digerente, Napoli, Italy; Western Regional Center, U.S. Department of Agriculture, Berkeley, California [J.E.B., D.D.K.J; Department of Comparative Toxicology and Ecotoxicology, Istituto Superiore di Sanità; Programme of Preventive Medicine, Project of Perinatal Pathologies and their Consequences, Consiglio Nazionale delle
\end{abstract} Ricerche, Roma, Italy [M.V., V.S.]

\begin{abstract}
In order to demonstrate that gliadin peptides may interact with cell membranes of celiac small intestinal mucosa, the capacity of these peptides to activate the cell membrane enzyme adenylate cyclase was tested. The addition of peptides from bread wheat purified A-gliadin and whole gliadin (proteins that are toxic for celiac patients) enhanced the adenylate cyclase activity of crude cell membrane preparations obtained from atrophic small intestinal mucosa of celiac patients. No activation of adenylate cyclase of this tissue was observed with peptides from proteins nontoxic for celiac patients (bread wheat albumin and maize prolamin). Gliadin peptides did not activate adenylate cyclase of morphologically normal small intestinal mucosa from normal subjects or from celiac patients in remission. These results, therefore, suggest that peptides from bread wheat gliadin may interact with cell membrane of atrophic small intestinal mucosa of celiac patients. (Pediatr Res 20: 42-44, 1986)
\end{abstract}

Celiac disease is a gliadin-dependent enteropathy. Humoraland cell-mediated immune hyperresponsiveness to wheat gliadin has been reported in celiac patients and it has been speculated that intestinal mucosa becomes a target of the immunological reaction after binding of gliadin-derived peptides (1). Gliadin peptides, obtained by simulating in vivo digestion, prevent in vitro morphological and biochemical recovery of atrophic small intestinal mucosa from celiac patients (2-7). They also cause reversible inhibition of in vitro differentiation and morphogenesis of rat fetal intestine (8), and reduce in vitro viability of human embryo and tumor cell lines (9). Interestingly, the same gliadin peptides do not exert any in vitro toxic effects on morphologically normal small intestinal mucosa from celiac patients in remission $(2-8,10)$ or from normal individuals $(8)$, on the differentiated jejunum from 21-day-old rat fetuses (8) or on adult human fibroblast cells (9). All these data indicate that gliadin peptides only interact with immature and/or undifferentiated cells. Previously, binding of wheat gluten to enterocytes of celiac mucosa has been observed using impure preparations and large amounts of the protein (11). This evidence has been recently questioned

Received March 15, 1985; accepted August 21, 1985

Address requests for reprints to Auricchio Salvatore, M.D., Cattedra di Clinica Pediatrica, II Facoltà di Medicina e Chirurgia, Via Sergio Pansini 5-80131 Napoli, Italy. since fluorescent techniques have failed to indicate binding of gliadin to the enterocytes (12).

Adenylate cyclase catalyses the formation of cAMP from ATP and increased levels of cAMP are associated with active secretion of electrolytes and secretion of water (13). This enzyme is situated at the lateral and basal membranes of the enterocyte and is activated by cholera and other bacterial toxins, prostaglandins and certain gut hormones. In the present paper we report that peptides obtained by sequential peptic and tryptic digestion of bread wheat purified A gliadin (14), as well as peptides obtained by peptic, tryptic and cotazym digestion of bread wheat whole gliadin (8), do interact with cell membranes from celiac patients, as shown by activation of the adenylate cyclase activity.

\section{MATERIALS AND METHODS}

Donors of intestinal mucosa specimens. Surgical biopsies with normal morphology were obtained from the first few centimeters of jejunum of 12 consenting adult patients undergoing surgery for peptic ulcer. Peroral biopsies with normal morphology were obtained from five celiac children in remission who had been on a gluten-free diet for at least 1 yr. Eighteen children with active celiac disease were new cases with typical clinical symptoms and subtotal mucosal atrophy of the small intestinal mucosa. Twelve biopsies revealing subtotal atrophy were obtained from children with celiac disease in relapse following 4 to 16 months of gluten challenge (mean 7.4 months). The ratio of villus height to crypt depth was less than 0.35 in all atrophic celiac mucosa. Three children affected by giardiasis and diarrhoea were also investigated; morphological appearance of these biopsied samples was that of a mild degree of partial mucosal atrophy.

Preparation of cell membrane pellets. Specimens obtained at biopsy were stored at $-80^{\circ} \mathrm{C}$ for periods of up to 6 months. They were thawed, washed in $0.154 \mathrm{NaCl}$ and homogenized in $0.5 \mathrm{ml}$ of ice cold buffer $\left(10 \mathrm{mM}\right.$ Tris $\mathrm{HCl}$, pH 7.4, $5 \mathrm{mM} \mathrm{MgCl}_{2}, 1$ mM EDTA, $3 \mathrm{mM}$ dithiothreitol, $0.25 \mathrm{M}$ sucrose) with 10 strokes using a Teflon-glass homogenizer. The homogenate was then centrifuged at $7000 \times g$ for $15 \mathrm{~min}$, and the pellet used for enzymic assay after suspension; final protein concentration was less than $1.5 \mathrm{mg} / \mathrm{ml}$.

Preparation of cereal protein digests. The peptic-tryptic-pancreatic digests of bread wheat gliadins or albumin and of maize prolamins were those described by Auricchio et al. $(15,16)$. The peptic-tryptic digest of A-gliadin was obtained as described by Frazer et al. (17); after the tryptic digestion, the sample was heated for $5 \mathrm{~min}$ in boiling water and clarified by centrifugation. 
Adenylate cyclase assay. Adenylate cyclase activity was assayed by measuring the conversion of $\alpha-\left[{ }^{32} \mathrm{P}\right] \mathrm{ATP}$ to $\left[{ }^{32} \mathrm{P}\right] \mathrm{CAMP}(18)$. Total reaction volume was $70 \mu$ and contained $0.1 \mathrm{mM}$ ATP, 6 $\mathrm{mM} \mathrm{MgCl}, 10 \mathrm{mM}$ Tris- $\mathrm{HCl}$ at $\mathrm{pH} 7.4,1 \mathrm{mg} / \mathrm{ml}$ bovine serum albumin, $10 \mathrm{mM}$ theophylline, $5 \times 10^{5} \alpha-\left[\mathrm{H}^{32} \mathrm{P}\right] \mathrm{ATP}$, an ATPregenerating system consisting of $2.6 \mathrm{mM}$ phosphoenol pyruvate and pyruvate kinase $(70 \mu \mathrm{g} / \mathrm{ml})$ and $0.5-0.8 \mathrm{mg} / \mathrm{ml}$ cell membrane proteins. Enzyme activity was assayed under basal condition and in the presence either of an optimal stimulating concentration of sodium fluoride $(10 \mathrm{mM})$ or of $90 \mu \mathrm{g} / \mathrm{ml}$ of cereal protein digests.

After $10 \mathrm{~min}$ of incubation at $37^{\circ} \mathrm{C}$ the reaction was stopped by the addition of $0.1 \mathrm{ml}$ of a solution containing $10 \mathrm{mM}$ ATP, $1 \mathrm{mM}$ cAMP, and $0.1 \mu \mathrm{Ci}$ of $\left[{ }^{3} \mathrm{H}\right] \mathrm{cAMP}$. Aliquots of the reaction mixture were chromatographed on silica gel plates with unlabeled ATP, cAMP, ADP and 3'AMP as markers, using isopropyl alcohol:water:ammonium hydroxide (7:2:1) as solvent. The spots were located under ultraviolet light, scraped from the plates, and counted (19). The $\left[{ }^{3} \mathrm{H}\right]$ cAMP served to determine the recovery of cAMP during the procedure. The recovery ranged from 70 to $80 \%$.

Protein assay. Protein concentration was determined with the method of Lowry et al. (20) after solubilization of membrane proteins in $1 \mathrm{~N} \mathrm{NaOH}$ and heating at $95^{\circ} \mathrm{C}$.

Reagents. ATP, cAMP, and ADP were obtained from Boeringher (Mannheim, West Germany), silicagel plates from Merck (Bracco, Milano, Italy), $\mathrm{H} \alpha-\left[{ }^{32} \mathrm{P}\right] \mathrm{ATP}$, and $\left[{ }^{3} \mathrm{H}\right] \mathrm{cAMP}$ from Amersham (Bucks, England); all the other materials were of reagent grade.

\section{RESULTS}

Basal adenylate cyclase activity was significantly higher in atrophic small intestinal mucosa of celiac patients than in morphologically normal small intestinal mucosa of celiac patients in remission or of control subjects. The enzyme activity was increased also in patients with giardiasis who were characterized by a mild degree of mucosal atrophy (Table 1).

The addition of the peptic-tryptic digest of purified A-gliadin from bread wheat or of the peptic-tryptic-cotazym digest of whole gliadin from bread wheat further increased basal adenylate cyclase activity of cell membrane preparations from atrophic celiac mucosa. On the contrary, these digests had no effect on adenylate cyclase activity from mucosa of patients with giardiasis and from morphologically normal mucosa from celiac patients in remission or control subjects (Tables 1 and 2). Furthermore, no activation of adenylate cyclase from atrophic celiac intestinal mucosa was observed with either the peptic-tryptic-cotazym digest of bread wheat albumin or maize prolamin (Table 2).

\section{DISCUSSION}

In agreement with the earlier findings by Tripp et al. (21), basal adenylate cyclase activity was increased in atrophic small intestinal mucosa of celiac patients; patients in remission had activities similar to the control group. As intestinal crypt cells are known to have a higher adenylate cyclase activity, these findings have been interpreted as an indication of a more immature character of surface enterocytes in active celiac disease (21). The similar increase of the adenylate cyclase activity found in the mucosa of patients with giardiasis and partial villous atrophy might be due to a similar mechanism (22) or to the stimulation of the enzyme activity by the protozoal infection.

The addition of peptides from bread wheat A-gliadin and whole gliadin, proteins that are toxic for celiac patients (14), further enhanced the adenylate cyclase activity of crude cell membrane preparations obtained from atrophic small intestinal mucosa of celiac patients. No activation of the adenylate cyclase of this tissue was observed with peptides from bread wheat albumin and maize prolamin, known to be nontoxic in celiac disease (23). Gliadin peptides did not activate the adenylate cyclase of mucosa from normal subjects or from celiac patients in remission.

These findings suggest that the enzyme activated by gliadin peptides in the atrophic celiac mucosa is either that of the immature surface enterocytes or, less probably, that of immunocytes, which are present in a high number in the mucosa of celiac patients with active disease. Studies on isolated enterocytes, if feasible, could clarify this question. It should also be clarified whether gliadin-induced activation of adenylate cyclase is specific for atrophic celiac mucosa, or whether it is also observed in other pathological conditions resulting in intestinal mucosa atrophy.

Our results suggest that bread wheat gliadin peptides interact with cell membranes of atrophic small intestinal mucosa of celiac patients, whereas peptides from proteins nontoxic in celiac disease do not. This effect could be related to the capacity of gliadin

Table 2. Adenylate cyclase in patients with celiac disease: in vitro effects of wheat gliadin and albumin peptides and of maize prolamins peptides

\begin{tabular}{|c|c|c|c|c|}
\hline \multirow{3}{*}{$\begin{array}{l}\text { Celiac patients with } \\
\text { active disease } \\
\text { (patient no.) }\end{array}$} & \multicolumn{4}{|c|}{$\begin{array}{l}\text { Adenylate cyclase activity } \\
\text { (pmol cAMP/mg protein } / 10 \mathrm{~min} \text { ) }\end{array}$} \\
\hline & \multicolumn{4}{|c|}{ Peptic-tryptic digest Peptic-tryptic-pancreatic } \\
\hline & Basal & of A-gliadin & & digest of: \\
\hline $1 *$ & 80 & 140 & $78)$ & \\
\hline $2 \dagger$ & 100 & 165 & 140 & Total wheat gliadins \\
\hline $3 \dagger$ & 130 & 200 & $180 J$ & \\
\hline $4 \dagger$ & 55 & 186 & 53 & \\
\hline $5^{*}$ & 152 & 269 & 151 & Wheat albumins \\
\hline $6 \dagger$ & 224 & 393 & 245 & \\
\hline $7^{*}$ & 80 & 160 & 781 & \\
\hline $8 \dagger$ & 150 & 250 & 145 & Maize prolamins \\
\hline
\end{tabular}

* New cases.

$\dagger$ In relapse after gluten challenge.

Table 1. Adenylate cyclase activity in patients with celiac disease or giardiasis: in vitro effects of sodium fluoride and of wheat gliadin peptides (mean $\pm 1 S D)$

Adenylate cyclase activity

(pmol cAMP/mg protein/10 min)

\begin{tabular}{|c|c|c|c|c|}
\hline \multirow[b]{2}{*}{ Subjects } & \multirow[b]{2}{*}{$n$} & & & \\
\hline & & Basal & $\begin{array}{l}\text { Sodium Fluoride } \\
\qquad(10 \mathrm{mM})\end{array}$ & $\begin{array}{l}\text { Peptic-tryptic digest of A-gliadin } \\
\qquad(90 \mu \mathrm{g} / \text { liter })\end{array}$ \\
\hline Control subjects & 12 & $68.0 \pm 24.1$ & $573.3 \pm 199.2$ & $72.8 \pm 35.9$ \\
\hline Celiac patients in remission & 5 & $65.8 \pm 14.6$ & $381.4 \pm 93.4$ & $85.0 \pm 34.7$ \\
\hline \multicolumn{5}{|l|}{ Celiac patients with active disease: } \\
\hline New cases & 18 & $148.6 \pm 85.7^{*}$ & $614.4 \pm 202.3$ & $248.6 \pm 110.6 \ddagger$ \\
\hline On relapse after gluten challenge & 12 & $185.7 \pm 94.0^{*}$ & $783.2 \pm 172.5$ & $291.4 \pm 173.3 \ddagger$ \\
\hline All cases & 30 & $163.5 \pm 89.5^{*}$ & $663.7 \pm 205.8$ & $265.7 \pm 137.9 \ddagger$ \\
\hline
\end{tabular}

Statistically different from controls: ${ }^{*} p<0.01, \dagger p<0.001$ (Student's $t$ test).

Statistically different from basal value: $\ddagger p<0.001$ (paired $t$ tests). 
peptides to exert in vitro toxic effects on immature and/or undifferentiated cells (15). The disappearance during enterocyte maturation of cell receptor sites for gliadin peptides could well explain the transient susceptibility of some tissues and cells to the in vitro toxic action of these peptides (15).

\section{REFERENCES}

1. Ströber W 1978 An immunological theory of gluten sensitive enteropathy. In: McNicholl BM, McCarthy CF, Fottrell PF (eds) Perspective in Coeliac Disease. Lancaster MTP Press, England, pp 169-182

2. Falchuk ZM, Gebhard RL, Sessoms C, Ströber W 1974 An in vitro model of gluten-sensitive enteropathy. J Clin Invest 53:487-500

3. Falchuk ZM, Katz AJ 1978 Organ culture model of gluten-sensitive enteropathy. In: McNicholl BM, McCarthy CF, Fottrell PF (eds) Perspective in Coeliac Disease. Lancaster MTP Press, England, pp 65-73

4. Fluge G, Aksnes L 1978 In vitro assessment of gluten toxicity by organ culture of human duodenal mucosa. In: McNicholl BM, McCarthy CF, Fottrell PF (eds) Perspective in Coeliac Disease. Lancaster MTP Press, England, pp 9199

5. Howdle PD, Corazza GR, Bullen AW, Losowsky MS 1979 In vitro demonstration of mucosal sensitivity to gluten. Gut 436-A

6. Jos J, Charbonnier L, Mougenot L, Mosse JF, Rey J 1978 Isolation and characterization of the toxic fraction of wheat gliadin in coeliac disease. In: McNicholl BM, McCarthy CF, Fottrell PF (eds) Perspective in Coeliac Disease. Lancaster MTP Press, England, pp 75-89

7. Jos J, Lenoir G, de Ritis G, Rey J 1975 In vitro pathogenetic studies of coeliac disease. Effects of protein on coeliac intestinal biopsy specimens maintained in culture for 48 hours. Scand J Gastroenterol 10:121-128

8. de Ritis G, Occorsio P, Auriccchio S, Gramenzi F, Morisi G, Silano V 1979 Toxicity of wheat flour proteins and protein-derived peptides for in vitro developing intestine from rat fetus. Pediatr Res 13:1255-1261

9. Rocca E, Paganuzzi Stammati A, Zampiglioni F, Zucco F 1983 Effects of gliadin-derived peptides from bread and durum wheats on in vitro cultures of human cells-lines. Implications for coeliac disease pathogenesis. Toxicol Lett 16:331-338

10. Fluge G, Aksnes L 1981 Morphological and morphometric assessment of human duodenal biopsies maintained in organ culture. In vitro influence of gluten in coeliac disease. Scand J Gastroenterol 16:555-567

11. Rubin W, Fauci AS, Sleisenger MH, Jeffries GH, Margolis S 1965 Immunofluorescent studies in adult coeliac disease. J Clin Invest 44:475-485

12. Stern M, Dietrich R 1982 Gliadin and Immunoglobulin containing cells of small intestinal lamina propria in childhood coeliac disease. Eur $\mathbf{J}$ Pediatr 139:13-17

13. Kimberg DV 1974 Cyclic nucleotides and their role in gastrointestinal secretion. Gastroenterology 67:1023-1064

14. Kasarda DD 1981 Toxic Protein and peptides in celiac disease. Relations to cereal genetics. In: Walcher DN, Kretchmer N (eds) Food Nutrition and Evolution. Masson, New York, pp 201-216

15. Auricchio S, Cardelli M, de Ritis G, De Vincenzi M, Latte F, Silano V 1984 An in vitro animal model for the study of cereal components toxic in coeliac disease. Pediatr Res 18:1372-1378

16. Auricchio S, de Ritis G, De Vincenzi M, Occorsio P, Silano V 1982 Effects of gliadin-derived peptides from bread and durum wheats on small intestine cultures from rat fetus and coeliac children. Pediatr Res 16:1004-1010

17. Frazer AC, Fletcher RF, Ross CA, Sammons HG, Schneider R 1959 Gluteninduced enteropathy: the effect of partially digestion of gluten. Lancet 2:252255

18. Mandato E, Meldolesi MF, Macchia V 1975 Diminished binding of thyroid stimulating hormone in a transplantable rat thyroid tumor as a possible cause of hormone unresponsiveness. Cancer Res 35:3089-3093

19. Salomon Y 1979 Adenylate cyclase assay In: Brook G, Greengard R, Robin GA (eds) Advances in Cyclic Nucleotide Research. Raven Press, New York pp 35-55

20. Lowry OH, Rosenbrough NJ, Fazz AL, Randall RJ 1951 Protein measurement with phenol. J Biol Chem 193:265-275

21. Tripp JH, Manning JA, Muller DPR, Walker-Smith JA, O'Donoghue DP, Kumar PJ, Harries JT 1978 Mucosal adenylate cyclase and sodium-potassium stimulated adenosine triphosphatase in jejunal biopsies of adults and children with coeliac disease. In: McNicholl BM, McCarthy CF, Fottrell PF (eds) Perspective in Coeliac Disease. Lancaster MTP Press, England, pp 461469

22. MacDonald TT, Ferguson A 1978 Small intestinal epithelial cell kinetics and protozoal infection in mice. Gastroenterology 74:496-500

23. Auricchio S, De Vizia B, Carta De Angelis L, Silano V 1974 Alpha-amylase protein inhibitors from wheat in coeliac disease. Lancet 1:98 